\title{
Responses of zinc recovery to temperature and mineral composition during sphalerite bioleaching process
}

\author{
Yunhua Xiao ${ }^{1,2}$, Xueduan Liư ${ }^{2}$, Jun Fang ${ }^{1}$, Yili Liang ${ }^{2}$, Xian Zhang ${ }^{2}$, Delong Meng ${ }^{2 *}$ and Huaqun Yin²*
}

\begin{abstract}
Temperature and energy resources (e.g., iron, sulfur and organic matter) usually undergo dynamic changes, and play important roles during industrial bioleaching process. Thus, it is essential to investigate their synergistic effects and the changes of their independent effects with simultaneous actions of multi-factors. In this study, we explored the synergistic effects of temperature and original mineral compositions (OMCs, energy resources) on the sphalerite bioleaching process. The microbial community structure was monitored by 165 rRNA gene sequencing technology and showed clear segregation along temperature gradients and Shannon diversity decreased at high temperature. On the contrary, the physicochemical parameters $\left(\mathrm{pH}\right.$ and $\left.\left[\mathrm{Fe}^{3+}\right]\right)$ in the leachate were significantly affected by the OMCs. Interestingly, the influence of temperature on zinc recovery was greater at relatively simpler OMCs level, whereas the influence of OMCs was stronger at lower temperature. In addition, using $\left[\mathrm{Fe}^{3+}\right], \mathrm{pH}$, relative abundances of dominant OTUs of microbial community and temperature as variable parameters, several models were constructed to predict zinc leaching efficiency, providing a possibility to predict the metal recovery efficiency under temperature change and variable energy resources.
\end{abstract}

Keywords: Temperature, Original mineral compositions, Microbial community, Zinc leaching efficiency, Models

\section{Introduction}

Seasonal and regional changes, accompanying changes of temperature and nutrient/energy resources, are regarded as two of main drivers regulating microbial diversity and function in natural ecosystem (Gilbert et al. 2012; Wang et al. 2016), e.g. marine ecosystem and forest soil ecosystem. However, due to the high richness and unculturable character of most species in the majority of natural ecosystems, the functions of microbes are still unclear and the importance of the change of community composition with temperature or nutrient increase/decrease is confusing (Streit and Schmitz 2004).

Bioleaching system is a relatively simpler ecosystem, since the species richness in this system is much lower than other ecosystems for its characters of low $\mathrm{pH}$ value

\footnotetext{
*Correspondence: meng.delong@ucdconnect.ie;

yinhuaqun_cs@sina.com

${ }^{2}$ School of Minerals Processing and Bioengineering, Central South

University, Changsha 410083, China

Full list of author information is available at the end of the article
}

and high heavy metal concentration. The dominant species in bioleaching systems are chemoautotrophic microbes, most of which has been isolated and identified, and their optimal growth conditions $(\mathrm{pH}$, temperature and energy resource, etc.), genome sequencing and function were well studied (Goto et al. 2002; Mangold et al. 2011; Justice et al. 2014; Bonnefoy and Holmes 2012). Therefore, it is suitable to use the bioleaching system to predict the variation of function via the change of microbial community under the change of temperature and energy resources.

Temperature of the surface layer is variable affected by seasonal and regional conditions in industrial bioleaching system. Many studies have o been done and planned to reveal the effects of temperature on bioleaching process (Behrad Vakylabad 2011; Watling et al. 2016). Behrad Vakylabad et al. (2011) reported that copper recovery was $87.52 \%$ at $50{ }^{\circ} \mathrm{C}$ with moderately thermophilic microorganisms and was $34.55 \%$ at $35^{\circ} \mathrm{C}$ with mesophilic microorganisms in chalcopyrite bioleaching. However, in these 
researches, single factor (temperature) was focused, whereas the differences of microbial community had been ignored at different temperature.

Studies (Basson et al. 2013; Mousavi et al. 2008; Shiers et al. 2014) found that, to some extent, energy resources (sulfur, iron or organic matter) could also enhance metal recovery. Mineral, which comprises sulfur and/or iron, is one kind of energy resource. Zhao et al. (2015) revealed that pyrite which had high concentration of iron enhanced the dissolution rate of chalcopyrite, which was consistent with Nazari et al. (2011). In addition, it consists of different minerals in natural mines, whereas the interaction between different minerals and the effects of multi-minerals on microbial community had always been neglected during bioleaching process.

There are three scientific questions in this study: (i) With simultaneous change of temperature and mineral composition, what was the responses of the microbial community, physicochemical parameters and metal recovery efficiency? (ii) What are the complex relationships among temperature, mineral composition, microbial community and zinc recovery? (iii) According to the known parameters, how to construct model to predict metal recovery efficiency? To explore these questions, in this study, four original mineral compositions were bioleaching at five different temperatures. 16S rRNA gene sequencing technology was used to monitor microbial community diversity and structure. Models were also constructed to predict zinc recovery efficiency using related parameters in bioleaching systems. The results gave us a better understanding of the influence of temperature and mineral composition on microbial community and metal recovery in bioleaching system, and suggested that the suitable shift of substrate (e.g., mineral composition and the concentration of ferric iron) and temperature enhanced metal recovery. These findings are meaningful in the industrial bioleaching systems and provide possible methods for predicting the ecosystem function following the change of temperature and energy resources.

\section{Materials and methods}

\section{Bacterial cultures, minerals, bioleaching treatments} and Illumina sequencing

In this study, the bacterial culture was enriched as described in our previous study (Xiao et al. 2015) and supplemental materials. Three minerals, sphalerite, pyrite and chalcopyrite, were utilized and the compositions were shown in Additional file 1: Table S1.

Bioleaching treatments, including four mineral composition treatments, which were sphalerite only (S), added with pyrite (SP, w/w, 1:1), with chalcopyrite (SC, w/w, 1:1) and with both (SPC, w/w/w, 1:1:1), were conducted at five different temperature treatments $(30,35,40,45$ and $50{ }^{\circ} \mathrm{C}$ ), respectively. All treatments $(4$ mineral treatments $\times 5$ temperature treatments) were carried out in septuplicate. The physicochemical parameters, including $\mathrm{pH}$, redox potential (ORP), the concentration of dissolved ferrous iron, total iron, copper ion, zinc ion and sulfate ion in the solution were monitored and a flask of each experimental group was removed for DNA extraction on day 6, 12, 21 and 30 (Xiao et al. 2015). Physicochemical parameters analyses, cells collection, DNA extraction, 16S rRNA gene Illumina sequencing and data processing were carried out as described previously (Xiao et al. 2015) and also see a detailed description in supplementary materials. The raw data of $16 \mathrm{~S}$ rRNA gene Illumina sequencing has been submitted to sequence read archive (SRA) of NCBI database and the accession number was SUB2165181.

\section{Statistical analysis}

Microbial community diversity was evaluated by Shannon diversity index (Shannon 1948). Differences were determined by a one-way analysis of variance followed by a Least Significant Difference test. Detrended correspondence analysis (DCA) was conducted to compare all samples of different bacterial community structures (at OTU level) and different OMCs, and principal component analysis (PCA) was conducted to compare all samples of different physicochemical parameters, All the analyses were performed in $\mathrm{R} v$. 3.1.12 with the vegan (v. 1.11-3) packages, Origin v 8.1, PermutMatrixEN or online (http://ieg.ou.edu/).

To explore relationships among temperature, physicochemical parameters, the OMCs, microbial community structure, microbial diversity (Shannon diversity index) and function (zinc leaching efficiency), Pearson correlation test and Partial Least Squares Path Modeling (PLSPM) was carried out (Sanchez et al. 2015). The whole physicochemical parameters were represented by the values of PC1 and PC2 (the top two axes) of PCA, and the OMCs and microbial community structure were represented by the values of DCA1 and DCA2 (the top two axes) by DCA. Three models by PLS-PM were conducted using temperature, the OMCs, physicochemical parameters/community structures/community diversity at four different stages, and zinc leaching efficiency.

\section{Prediction model of zinc leaching efficiency}

Multiple linear regression analysis (MLR) and neural network were applied to construct the models to predict zinc leaching efficiency in response to the changes of temperature, the OMCs, ferric iron, $\mathrm{pH}$ value and dominant OTUs. MLR is a simple model, while neural network is a method to capture and model the complex 
interactions between zinc leaching efficiency and the various parameters (Larsen et al. 2012). In this study, we use two packages, neuralnet (v. 1.33) and nnet (v. 7.3-10) in $\mathrm{R}$ software. The best-fitted equations based on the optimality criteria were then used for the prediction. In the formula search, data from 50 randomly selected samples of total 80 samples were used for model training. After gaining the best-fitted equation, the remaining 30 samples were imported to validate this equation. The random samples were reshuffled 10 times.

The goodness of fit with models was assessed by the coefficient of determination $\left(\mathrm{R}^{2}\right)$ and Akaike information criterion (AIC) (Zhou et al. 2016). The coefficient of determination is defined as: $\mathrm{R}^{2}=1-\mathrm{SSR} /$ TSS, where SSR is the sum of squares of residuals and TSS is the total sum of squares; The AIC is defined as: AIC $=-2 \times \ln (\mathrm{L})+2 \mathrm{n}$, where $\mathrm{L}$ is the probability of the data given a model and $\mathrm{n}$ is the number of parameters (Zhou et al. 2016). Better model fits with greater $R^{2}$ value (smaller SSR value) and smaller AIC value.

\section{Results \\ Effects of temperature and mineral composition on zinc recovery}

The rate of mineral decomposition and zinc leaching efficiency differed among treatments at different stages (Additional file 1: Table S2). On day 30, zinc leaching efficiency was $66.3 \%$ at $30{ }^{\circ} \mathrm{C}, 72.2 \%$ at $35{ }^{\circ} \mathrm{C}, 71.2 \%$ at $40{ }^{\circ} \mathrm{C}, 78.2 \%$ at $45{ }^{\circ} \mathrm{C}$ and $89.1 \%$ at $50{ }^{\circ} \mathrm{C}$ in $\mathrm{S}$ group, and it was $80.7 \%$ at $30{ }^{\circ} \mathrm{C}, 86.5 \%$ at $35{ }^{\circ} \mathrm{C}, 84.6 \%$ at $40{ }^{\circ} \mathrm{C}, 94.5 \%$ at $45{ }^{\circ} \mathrm{C}$ and $97.2 \%$ at $50{ }^{\circ} \mathrm{C}$ in $\mathrm{S}$ group (Fig. 1A), which indicated that higher temperature could lead to higher zinc leaching efficiency. It was not consistently with that in SC and SPC groups. In SC group, zinc leaching efficiency was the lowest at $40{ }^{\circ} \mathrm{C}(74.1 \%)$ and was the highest at $30(84.4 \%)$ and $50{ }^{\circ} \mathrm{C}(82.9 \%)$. In SPC group, zinc leaching efficiency was the highest at $30{ }^{\circ} \mathrm{C}(85.8 \%)$ and was the lowest at $50{ }^{\circ} \mathrm{C}$ (78.9\%). Figure 1B showed that zinc leaching efficiency was higher in SP group than that in S group at 5 different temperature gradients, however, it was higher in SC and SPC group than that in S group at lower temperature (30, 35 and $40^{\circ} \mathrm{C}$ ), and was lower than that in $\mathrm{S}$ group at $50^{\circ} \mathrm{C}$.

\section{Variation of physicochemical parameters during sphalerite bioleaching process}

The variations of physicochemical parameters, e.g., $\mathrm{pH}$, ORP, concentration of $\mathrm{Fe}^{3+}$, were shown in Additional file 1: Table S3. In all treatments, the $\mathrm{pH}$ value and the concentration of $\mathrm{Fe}^{2+}$ decreased gradually, while ORP and the concentrations of $\mathrm{Fe}^{3+}, \mathrm{SO}_{4}{ }^{2-}, \mathrm{Zn}^{2+}$ and $\mathrm{Cu}^{2+}$ increased gradually. Figure $2 \mathrm{a}, \mathrm{b}$ showed that the variation trends of $\mathrm{pH}$ value and the concentration of ferric iron were not regular with an increase of temperature under different $\mathrm{OMCs}$ on day 30. In $\mathrm{S}$ group, the lowest $\mathrm{pH}$ value was 0.86 at $50{ }^{\circ} \mathrm{C}$, and the highest was 1.52 at $35{ }^{\circ} \mathrm{C}$; in SP group, the lowest was 0.795 at $50{ }^{\circ} \mathrm{C}$, and the highest was 1.105 at $35{ }^{\circ} \mathrm{C}$; in SC group, the lowest was 1.025 at $30^{\circ} \mathrm{C}$, and the highest was 1.285 at $35^{\circ} \mathrm{C}$; in SPC group, the lowest was 0.885 at $40^{\circ} \mathrm{C}$, and the highest was 1.16 at $35^{\circ} \mathrm{C}$. In $\mathrm{S}$ group, the highest ferric iron concentration was $3.78 \mathrm{~g} / \mathrm{L}$ at $50^{\circ} \mathrm{C}$, and the lowest was $2.40 \mathrm{~g} / \mathrm{L}$ at $45{ }^{\circ} \mathrm{C}$; in SP group, the highest was $6.25 \mathrm{~g} / \mathrm{L}$ at $50{ }^{\circ} \mathrm{C}$, and the lowest was $4.71 \mathrm{~g} / \mathrm{L}$ at $40{ }^{\circ} \mathrm{C}$; in $\mathrm{SC}$ group, the highest was $2.78 \mathrm{~g} / \mathrm{L}$ at $35^{\circ} \mathrm{C}$, and the lowest was $2.00 \mathrm{~g} / \mathrm{L}$ at $40{ }^{\circ} \mathrm{C}$; in $\mathrm{SPC}$ group, the highest was $4.35 \mathrm{~g} / \mathrm{L}$ at $45^{\circ} \mathrm{C}$, and the lowest was $2.82 \mathrm{~g} / \mathrm{L}$ at $50{ }^{\circ} \mathrm{C}$. Figure $2 \mathrm{c}$, d showed that the $\mathrm{pH}$ value showed decreasing trend and the concentration of ferric iron showed increasing trend with the increase of iron proportion in different OMCs under different temperature (except for $50{ }^{\circ} \mathrm{C}$ ) on day 30 .

PCA was conducted to compare the physicochemical parameters of all treatments (Fig. 3). It showed that the OMCs (Fig. 3b), rather than temperature (Fig. 3a), had a significant effect on physicochemical parameters. In addition, the physicochemical parameters were also significantly different between bioleaching stages (day 6, 12, 21 and 30, Fig. 3c).

\section{Overview of microbial community}

In order to reveal the effects of temperature and the OMCs on the microbial community during the sphalerite bioleaching process, 16S rRNA gene sequencing was conducted. After clustering at $97 \%$ sequence identity, 405 OTUs were identified in this study. Among these, 394 OTUs (97.28\%) were classified in the domain Bacteria. Within the domain Bacteria, the dominant phyla were Proteobacteria, Firmicutes and Nitrospirae, which accounted for above $84.3 \%$ of all reads (Additional file 1: Figure S1). Within the domain Archaea, the dominant phylum was Euryarchaeota, which accounted for about $0-15.67 \%$ in this study. Acidithiobacillus (1.72-93.86\%) and Acidiphilium (0-5.59\%) were the dominant genera within the phylum Proteobacteria, Sulfobacillus (0.28-93.53\%) within phylum Firmicutes, Leptospirillum (0-74.05\%) within the phylum Nitrospirae, and Ferroplasma (0-15.96\%) within the phylum Euryarchaeota (Additional file 1: Figure S2). In addition, the unclassified genera were accounted for $0-22.13 \%$, which was mostly affiliated with Proteobacteria.

\section{Effects of temperature and mineral composition} on microbial community structure and diversity

Comparison of the taxonomic populations among the 20 treatments was conducted to determine how populations, structure and diversity responded to the different temperature and mineral compositions. 

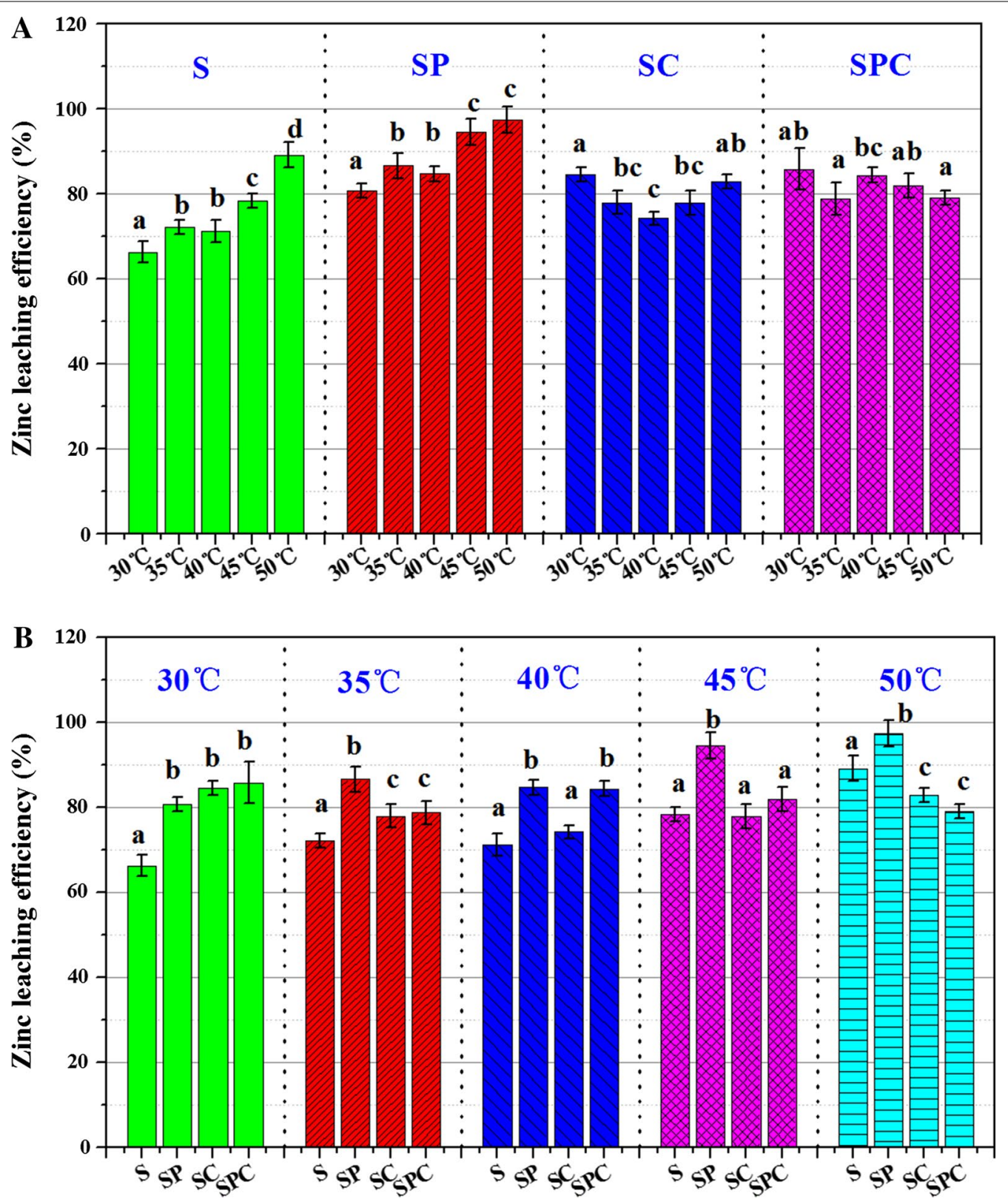

Fig. 1 Zinc leaching efficiency on day 30 under different temperature (A) and mineral composition (B)

We compared the differences of microbial compositions at genera level (Additional file 1: Figure S2) and found that relative abundances of some genera were affected by the OMCs or temperature. It showed that, compared with S group, high abundance was in SP, SC and SPC groups. In S group, Leptospirillum accounted for a certain proportion (> 1\%) at 30 and $35{ }^{\circ} \mathrm{C}$ on day 30 . In other three groups, compared with $30,35,40$ and $45{ }^{\circ} \mathrm{C}$, few Leptospirillum was detected at $50{ }^{\circ} \mathrm{C}$. Higher relative abundances of Sphingobacterium were at 45 or $50{ }^{\circ} \mathrm{C}$ than that at 30,35 and $40{ }^{\circ} \mathrm{C}$. Certain abundances of Alicyclobacillus were detected at $40{ }^{\circ} \mathrm{C}$ in S and SP group. Acidiphilium were only detected at $30{ }^{\circ} \mathrm{C}$ at the initial stage (day 6 and 12).

Microbial compositions changed more obviously at the OTU level (Fig. 4a). For example, although six OTUs, including OTU_1, OTU_5, OTU_6, OTU_7, OTU_22 and OTU_144, were all affiliated to Sulfobacillus, their responses to the temperature and mineral composition were different. With the effects of temperature, OTU_1 was more abundant at 30 and $40{ }^{\circ} \mathrm{C}$, OTU_5 and OTU_7 were more abundant at $40{ }^{\circ} \mathrm{C}$, OTU_6 was 

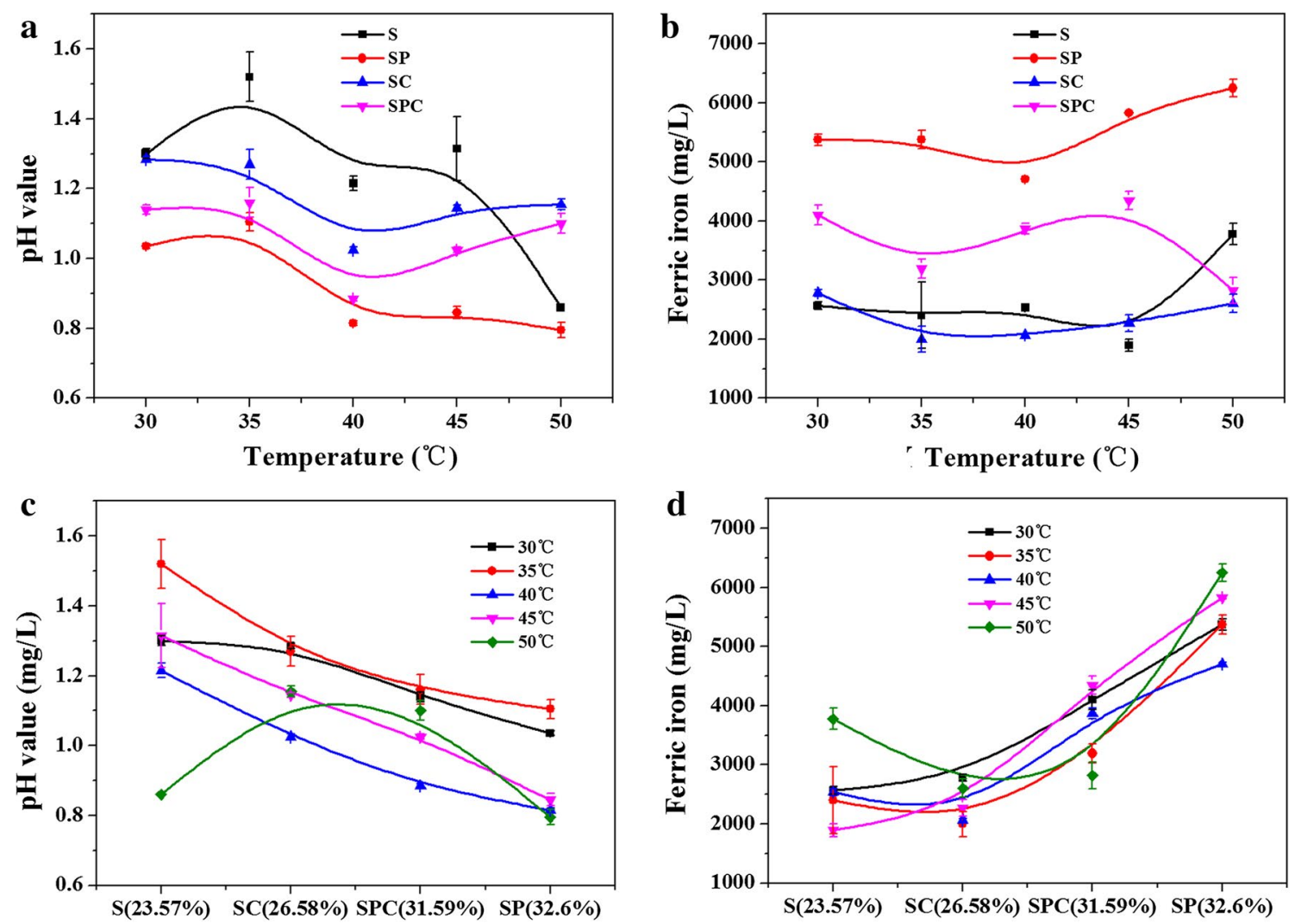

The proportion of iron in mineral compositon

The proportion of iron in mineral compositon

Fig. $2 \mathrm{pH}$ value and the concentration of ferric iron on day 30 under different temperature (a pH; b ferric iron) and different mineral composition (c $\mathrm{pH}$; d ferric iron)

more abundant at $30^{\circ} \mathrm{C}$, OTU_22 was more abundant at $50{ }^{\circ} \mathrm{C}$; With the effects of mineral composition, OTU_1 was more abundant in S and SP, OTU_6 was more abundant in S, SP and SPC groups, and OTU_5, OTU_7 and OTU_144 were more abundant in SC and SPC groups. The similarity was found in Acidithiobacillus. OTU_2 was showed no significant different in all treatments, but OTU_4 and OTU_208 were more abundant at 30 and $35^{\circ} \mathrm{C}$, and OTU_208 were more abundant in SP and SPC groups. Results of NCBI blast (nr/nt database) showed the taxa of the top 17 OTUs (Additional file 1: Figure S3), indicating that the OTUs, affiliated to the same genus, might be different species or be different strains of the same genus. For example, OTU_1 belonged to $S$. thermotolerans strain $\mathrm{Kr} 1$ (98\%), while OTU_6 belonged to $S$. acidophilus strain DSM 10332 (96\%).

Due to the effects of temperature and the OMCs on OTUs, the Shannon diversity was also influenced (Additional file 1: Table S4). On the one hand, it has been found that relatively higher temperature would lead to lower Shannon diversity index. For example, in SP group on day 21, the Shannon diversity index was 2.136 at $30{ }^{\circ} \mathrm{C}, 1.307$ at $35{ }^{\circ} \mathrm{C}, 1.406$ at $40{ }^{\circ} \mathrm{C}, 1.176$ at $45^{\circ} \mathrm{C}$ and 0.835 at $50{ }^{\circ} \mathrm{C}$. On the one hand, the Shannon diversity index was different under different OMCs. For example, at $30^{\circ} \mathrm{C}$ on day 21, it was 1.257 in S group, 2.136 in SP group, 1.807 in SC group and 1.312 in SPC group, while at $50{ }^{\circ} \mathrm{C}$ on day 21 , it was 0.849 in S group, 0.835 in SP group, 0.845 in SC group and 0.910 in SPC group. However, it seemed that the change of the OMCs had a certain but not a regular effect on Shannon diversity index.

To explore the differences of the whole microbial community structure under different temperature and OMCs, DCA was conducted (Fig. 4). It showed that samples at different temperature could separate from each other, except some samples at 35 and $45{ }^{\circ} \mathrm{C}$, while samples in different OMCs and at different bioleaching stage could not separate from the other groups.

\section{Relationship among temperature, mineral composition, physicochemical parameters, microbial community structure, microbial diversity and zinc leaching efficiency} To explore the relationships among temperature, the OMCs, physicochemical parameters, microbial community 

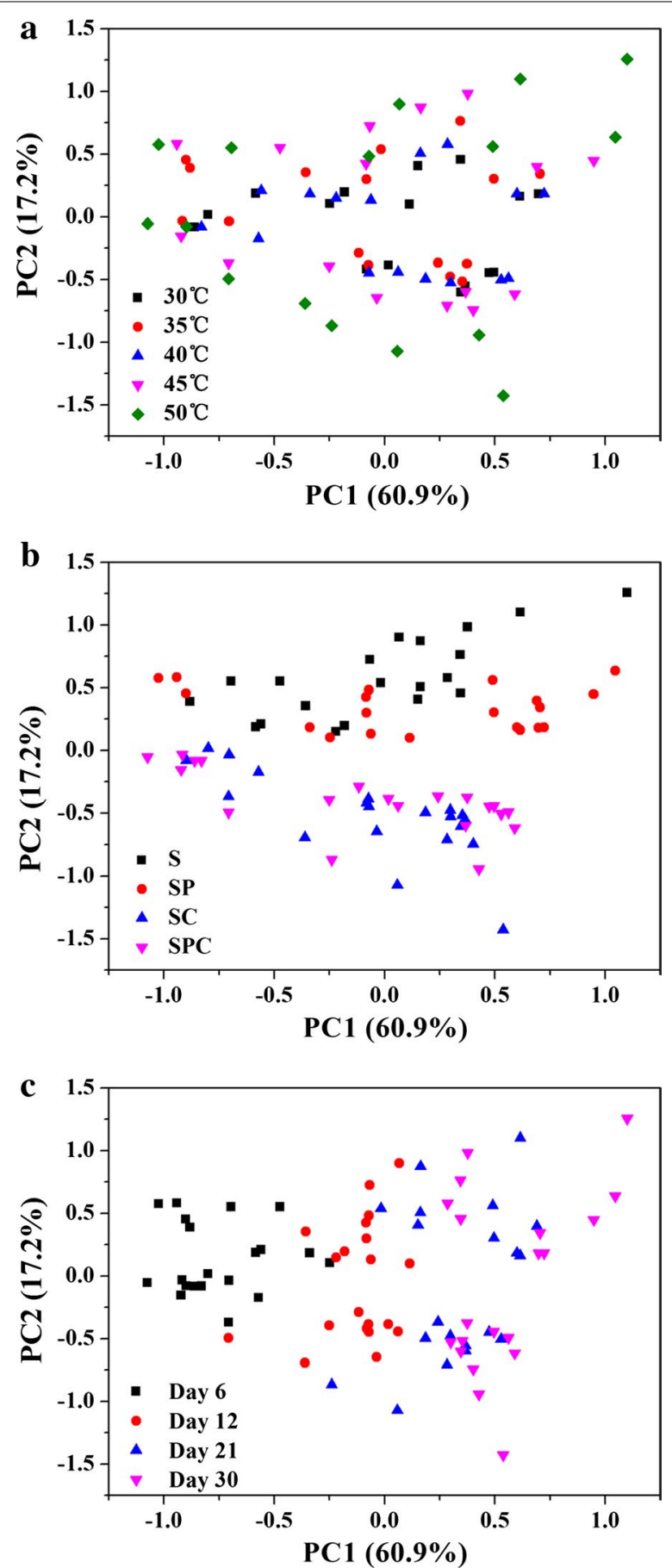

Fig. 3 Plot of physicochemical parameters of all samples under different temperature (a), mineral composition (b) and stages (c) using principal component analysis (PCA)

structure, microbial diversity and zinc leaching efficiency in bioleaching system at the whole level, Partial Least Squares Path Modeling (PLS-PM) was used and the result was shown in Fig. 5. In this model, physicochemical parameters, including $\mathrm{pH},\left[\mathrm{Fe}^{2+}\right],\left[\mathrm{Fe}^{3+}\right]$, ORP, $[\mathrm{Cu}],\left[\mathrm{SO}_{4}{ }^{2-}\right]$ and $[\mathrm{Zn}]$, were represented by the values of PC1 and PC2 (the top two axes) of PCA. Shannon diversity index represented microbial diversity. The OMCs and microbial community structure were represented by the values of DCA1 and DCA2 (the top two axes) of DCA. Zinc leaching efficiency was important in sphalerite bioleaching system, and thus it still represented the function of the microbial community. In addition, the physicochemical parameters, microbial community structure and microbial diversity were utilized at the four stages (day 6, 12, 21 and 30), respectively. Temperature $(r=0.381)$ and the OMCs $(r=-0.355)$ were both correlated to zinc leaching efficiency. Zinc leaching efficiency had significant relationships $(r>0.300, p<0.05)$ with the physicochemical parameters and Shannon diversity index on day 12 and 21 also, and microbial community structure on day 6 and 30. This model also showed that temperature was significantly influenced microbial community structure and Shannon diversity index, while had no significant effects on physicochemical parameters. On the contrary, the OMCs was significantly correlated to physicochemical parameters, while had no significant effects on microbial community structure and Shannon diversity index.

Besides, in order to better understand the effects of relative abundance of each OTU and each physicochemical parameter on zinc leaching efficiency at the final stage (on day 30), Pearson correlation tests were conducted at the four stages, respectively (Table 1, Additional file 1: Table S5 and Table 2). Among these 405 OTUs, zinc leaching efficiency was significantly correlated to 8 OTUs on day 6 , to 3 OTUs on day 12 , to 23 OTUs on day 21 and to 47 OTUs on day 30 (Additional file 1: Table S5). Among the 17 dominated OTUs, OTU_1 (on day 6, 12 and 21), OTU_4 (on day 21) and OTU_6 (on day 21) were significantly $(p<0.05)$ or marginally significantly $(p<0.1)$ and negatively correlated to zinc leaching efficiency, and OTU_2 (on day 6 and 12) and OTU_5 (on day $6)$ were $(\mathrm{p}<0.05)$ or marginally significantly $(p<0.1)$ and positively correlated to zinc leaching efficiency. Ferrous iron on day 6 and ferric iron on day 21 and 30 was significantly positive correlated to zinc leaching efficiency. The $\mathrm{pH}$ value and sulfate ion was also significantly correlated to zinc leaching efficiency. However, the correlation between $\mathrm{pH}$ value and zinc leaching efficiency was positive on day 6 and was negative on day 21 and 30 .

\section{Model construction to predict zinc leaching efficiency}

In this study, we explored the effect of temperature and the OMCs on sphalerite bioleaching, thus it was important whether temperature and the OMCs could predict zinc leaching efficiency at different stages. Multivariate linear regression was used to construct the predicting model (Table 3 ). The results showed that the models with temperature and the OMCs as the variable 

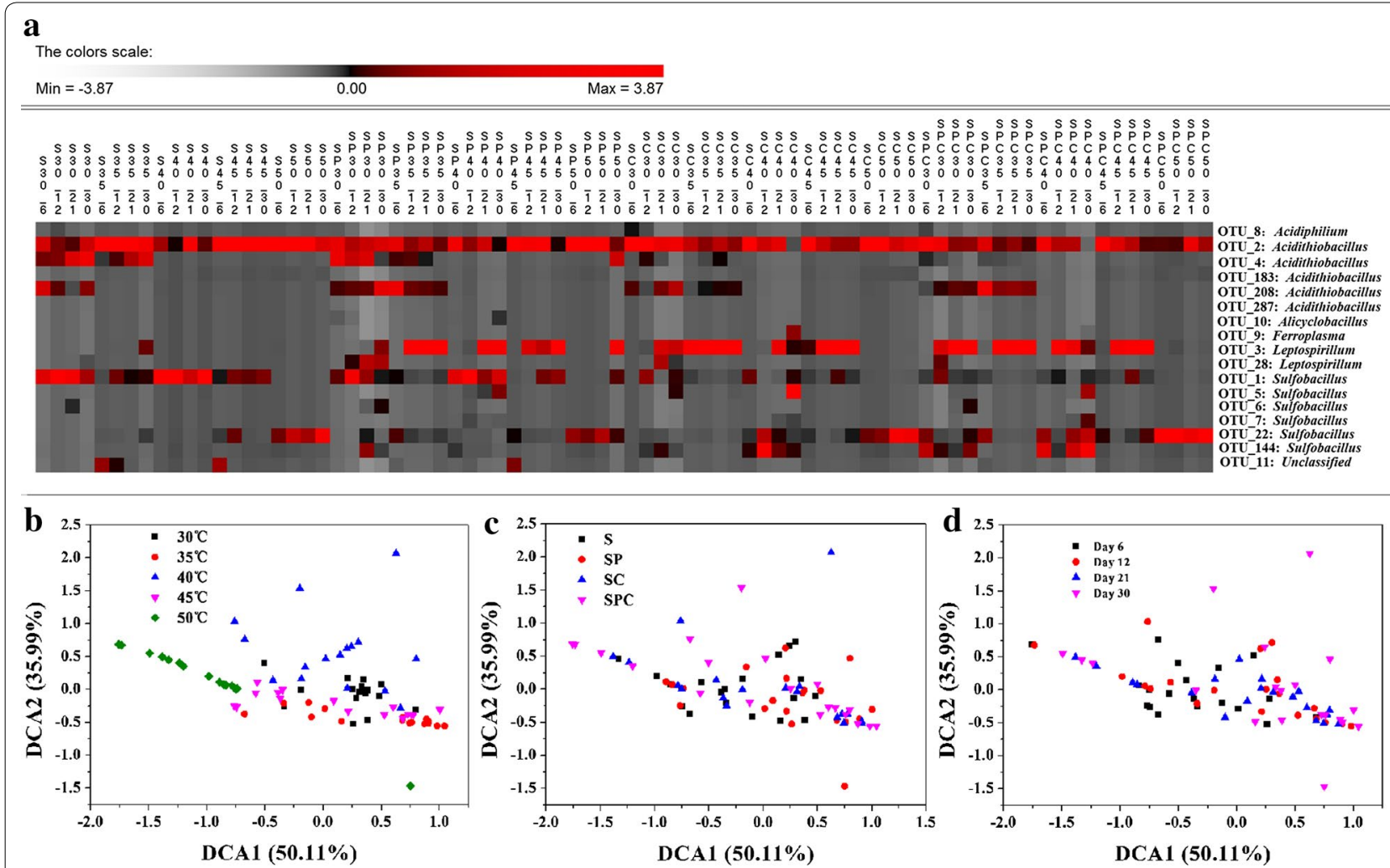

Fig. 4 Polts of microbial community composition at OTU level (a) and microbial community structure under different temperature (b), mineral composition (c) and stages (d) using detrended correspondence analysis (DCA)

parameters could predict zinc leaching efficiency on day $6\left(R^{2}=0.443, p=0.006\right)$ and on day $30\left(R^{2}=0.512\right.$, $p=0.002)$, but could not $(p>0.1)$ on day 12 and 21 .

Through the above results, we know zinc leaching efficiency was significantly associated with microbial community, physicochemical parameters, temperature and the OMCs. Therefore, we could choose some of them to construct models to predict zinc leaching efficiency by multivariate linear regression. Firstly, considering that OMCs changed during bioleaching process, physicochemical parameters were significantly affected by mineral composition and the directly related reaction might be sulfur/iron oxidization, $\mathrm{pH}$ and the concentration of $\mathrm{Fe}^{3+}$ were chosen to represent the OMCs. Secondly, microbial community was complex, while the key OTUs might be relatively stable. OTU_1 (98\% similarity to $S$. thermotolerans $\mathrm{Kr} 1$ ) and OTU_2 (98\% similarity to $A$. caldus $\mathrm{KU}$ ) were two of the most dominant OTUs and they were significantly correlated to zinc leaching efficiency, therefore, they were chosen to represent the microbial community. Seven multivariate linear regression models were constructed with 80 samples (Fig. 6). The independent variables were temperature in model
1; $\mathrm{pH}$ and the concentration of $\mathrm{Fe}^{3+}$ in model 2; OTU_1 and OTU_2 in model 3; temperature, $\mathrm{pH}$ and the concentration of $\mathrm{Fe}^{3+}$ in model 4; temperature, OTU_1 and OTU_2 in model 5; pH, the concentration of $\mathrm{Fe}^{3+}$, OTU_1 and OTU_2 in model 6; all factors in model 7. Among these models, model $2\left(\mathrm{R}^{2}=0.575, \mathrm{p}<0.001\right.$, $\mathrm{AIC}=6.479), 4\left(R^{2}=0.649, p<0.001, A I C=6.302\right), 5$ $\left(R^{2}=0.656, p<0.001, \mathrm{AIC}=6.298\right)$ and $7\left(\mathrm{R}^{2}=0.695\right.$, $\mathrm{p}<0.001$, AIC $=6.193$ ) could well predict zinc leaching efficiency, on the contrary, model $1\left(R^{2}=0.018, p=0.12\right.$, $A I C=7.301), 3\left(R^{2}=0.145, p<0.001, A I C=7.177\right)$ and $6\left(R^{2}=0.208, p<0.001, A I C=7.115\right)$ could not. It suggested that the models (model 7) with these five parameters were better fits.

Considering the MLR models were too simple to predict, we compared this method with two kinds of neural network (neuralnet and nnet packages). Using the three constructed models with 50 samples, we predicted zinc leaching efficiency of the remained 30 samples (Fig. 7). The SSR value and AIC value of MLR model (5507.5 $\pm 949.8 ; 6.54)$ and nnet model $(5128.0 \pm 1220.0$; 6.47) showed no significance, which were both smaller than that of neuralnet model $(9277.4 \pm 2749.7 ; 7.06)$. 


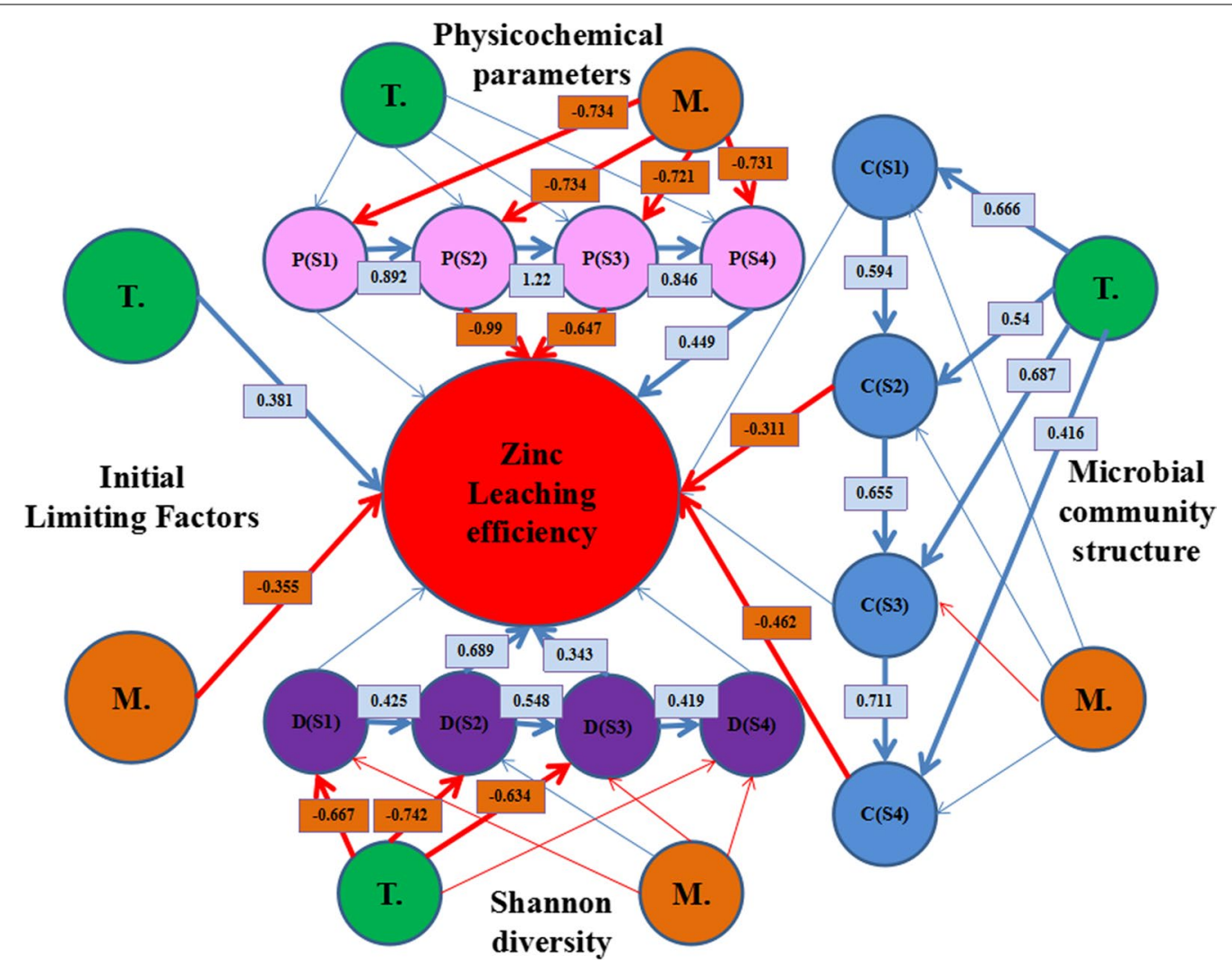

Fig. 5 The direct and indirect effects of temperature and the original mineral composition on zinc leaching efficiency. The effects of temperature, mineral composition and physicochemical parameters (model 1)/microbial community structure (model 2)/microbial diversity (model 3) on zinc leaching efficiency, explored with Partial Least Squares Path Modeling (PLS-PM). Mineral composition and microbial community structure were represented by the top two axes (DCA1 and DCA2) of DCA. The whole physicochemical parameters was represent by the values of PC1 and PC2 (the top two axes) of PCA. The blue line represented the positive correlation, and the red line represented the negative correlation. The bold line showed the relation was significant $(p<0.05)$ or marginally significant $(p<0.1)$ and the regular line showed the relation was no significant. Models were assessed using goodness of fit (GoF) statistic. The GoFs for model 1-3 were 0.642, 0.599 and 0.642 , respectively

Therefore, it indicated that in this simple system, MLR models might predict the function of zinc leaching efficiency well.

\section{Discussion}

Temperature and energy resource components are two major factors in biological processes (Rosenblatt and Schmitz 2016), such as sewage sludge treatment (Tyagi et al. 1994; Wong et al. 2015; Pathak et al. 2009), methane generation (Conrad et al. 2009; Yvon-Durocher et al. 2014), and organic matter (aromatic, dairy manure, cellulose, etc.) degradation (Hartmann and Ahring 2005), affecting microbial community. We explored the responses of the microbial community and eco-system function (metal recovery ability) to temperature or nutrient/energy resource in bioleaching system due to its simple and relatively well-known specificity. Via converting the microbial community and physicochemical parameters, Temperature (Behrad Vakylabad 2011; Watling et al.
2016) and energy resource (Sreekrishnan et al. 1996; Garrido et al. 2008) affected mineral dissolution. Our results indicated that composition and structure of microbial community were temperature sensitive, while physicochemical parameters were mainly affected by the OMCs. Besides, temperature (accompanying variations of the microbial community) and the OMCs (accompanying variations of physicochemical parameters) could both convert and predict zinc leaching efficiency.

\section{Temperature altered microbial community and zinc leaching efficiency}

Temperature is one of the main environmental factors governing microbial life, which is a kind of selective pressure for activity, density and composition of microorganisms (Aragno 1981). Therefore, there is no wonder that microorganisms are most often chosen as models for studying the effects of temperature on biological processes. Some species ranged from low to high abundance 
Table 1 The correlation between zinc leaching efficiency on day 30 and the dominant OTU at different stages

\begin{tabular}{|c|c|c|c|c|c|c|c|c|}
\hline \multirow[t]{2}{*}{ OTU } & \multicolumn{2}{|l|}{ Day 6} & \multicolumn{2}{|l|}{ Day 12} & \multicolumn{2}{|l|}{ Day 21} & \multicolumn{2}{|l|}{ Day 30} \\
\hline & $r$ & $p$ & $r$ & $p$ & $r$ & $p$ & $r$ & $p$ \\
\hline OTU_1 & -0.384 & 0.095 & -0.435 & 0.055 & -0.538 & 0.014 & -0.304 & 0.192 \\
\hline OTU_2 & 0.380 & 0.098 & 0.457 & 0.043 & 0.197 & 0.405 & -0.217 & 0.359 \\
\hline OTU_3 & -0.101 & 0.671 & 0.230 & 0.329 & 0.091 & 0.704 & 0.357 & 0.122 \\
\hline OTU_4 & -0.071 & 0.768 & -0.177 & 0.456 & -0.543 & 0.014 & -0.337 & 0.147 \\
\hline OTU_5 & 0.509 & 0.022 & 0.184 & 0.437 & 0.277 & 0.237 & -0.026 & 0.915 \\
\hline OTU_6 & 0.000 & 1.000 & 0.110 & 0.644 & -0.438 & 0.053 & 0.171 & 0.471 \\
\hline OTU_7 & 0.207 & 0.381 & 0.215 & 0.362 & 0.128 & 0.591 & 0.075 & 0.753 \\
\hline OTU_8 & 0.220 & 0.352 & -0.024 & 0.920 & -0.337 & 0.146 & 0.312 & 0.180 \\
\hline OTU_9 & 0.363 & 0.116 & 0.320 & 0.169 & -0.136 & 0.568 & -0.141 & 0.555 \\
\hline OTU_10 & 0.070 & 0.768 & 0.152 & 0.523 & -0.263 & 0.263 & 0.120 & 0.613 \\
\hline OTU_11 & -0.217 & 0.359 & -0.130 & 0.584 & -0.327 & 0.159 & 0.000 & 1.000 \\
\hline OTU_22 & 0.164 & 0.489 & 0.070 & 0.769 & 0.261 & 0.267 & 0.153 & 0.519 \\
\hline OTU_28 & -0.002 & 0.992 & 0.239 & 0.311 & 0.164 & 0.490 & 0.001 & 0.997 \\
\hline OTU_144 & 0.140 & 0.556 & -0.172 & 0.469 & 0.047 & 0.843 & 0.102 & 0.670 \\
\hline OTU_183 & 0.118 & 0.620 & 0.346 & 0.135 & 0.137 & 0.565 & -0.003 & 0.990 \\
\hline OTU_208 & -0.067 & 0.780 & -0.262 & 0.264 & -0.010 & 0.966 & -0.103 & 0.667 \\
\hline OTU_287 & 0.024 & 0.920 & -0.298 & 0.201 & 0.181 & 0.446 & 0.043 & 0.856 \\
\hline
\end{tabular}

Significant $(p<0.05)$ and marginally significant $(p<0.1)$ differences were indicated in italics

Table 2 The correlation between zinc leaching efficiency on day $\mathbf{3 0}$ and individual physicochemical parameter at different stages

\begin{tabular}{|c|c|c|c|c|c|c|c|c|}
\hline \multirow[t]{2}{*}{ Physicochemical parameters } & \multicolumn{2}{|l|}{ Day 6} & \multicolumn{2}{|l|}{ Day 12} & \multicolumn{2}{|l|}{ Day 21} & \multicolumn{2}{|l|}{ Day 30} \\
\hline & $r$ & $\mathbf{p}$ & $r$ & $\mathbf{p}$ & $r$ & $\mathbf{p}$ & $r$ & $\mathbf{p}$ \\
\hline $\mathrm{pH}$ & 0.492 & 0.028 & -0.180 & 0.449 & -0.616 & 0.004 & -0.814 & 0.000 \\
\hline ORP & -0.003 & 0.989 & -0.075 & 0.755 & 0.274 & 0.242 & 0.410 & 0.073 \\
\hline $\mathrm{Fe}^{2+}$ & 0.455 & 0.044 & -0.035 & 0.883 & -0.250 & 0.287 & -0.216 & 0.360 \\
\hline $\mathrm{Fe}^{3+}$ & -0.059 & 0.804 & 0.208 & 0.380 & 0.543 & 0.014 & 0.744 & 0.000 \\
\hline $\mathrm{SO}_{4}^{2-}$ & 0.407 & 0.075 & 0.592 & 0.006 & 0.745 & 0.000 & 0.786 & 0.000 \\
\hline $\mathrm{Zn}^{2+}$ & 0.397 & 0.083 & 0.293 & 0.211 & 0.145 & 0.541 & 0.068 & 0.777 \\
\hline $\mathrm{Cu}^{2+}$ & -0.130 & 0.586 & -0.122 & 0.610 & -0.094 & 0.694 & -0.088 & 0.712 \\
\hline
\end{tabular}

Significant differences $(p<0.05)$ were indicated in italics

Table 3 Multiple regression analysis between zinc leaching efficiency and mineral composition on sampling time

\begin{tabular}{llll}
\hline Time & Formula & $\mathbf{R}^{\mathbf{2}}$ & $\mathbf{p}$ \\
\hline Day 6 & $y=2.800+0.816 \mathrm{x}_{1}+721.911 \mathrm{x}_{2}-741.258 \mathrm{x}_{3}$ & 0.443 & 0.006 \\
Day 12 & - & 0.147 & $>0.1$ \\
Day 21 & - & 0.038 & $>0.1$ \\
Day 30 & $y=62.266+0.479 x_{1}+462.157 x_{2}-470.054 x_{3}$ & 0.512 & 0.002
\end{tabular}

Zinc leaching efficiency was indicated by " $y$ " (unit: \%), temperature was indicated by " $\mathrm{x}_{1}$ " (unit: ${ }^{\circ} \mathrm{C}$ ) and mineral composition was indicated by " $\mathrm{x}_{2}{ }^{\text {" }}$ (DCA1) and " $x_{3}$ " (DCA2) under temperature variation, and similar results were obtained in different fields, such as freshwater pond (Lear et al. 2014), marine (Gilbert et al. 2012), and soil (Deangelis et al. 2015; Karhu et al. 2014). Deangelis et al. (2015) reported that some members of the Actinobacteria, Alphaproteobacteria and Acidobacteria showed strong warming responses in temperate forest soils, with one Actinomycete decreasing from 4.5 to $1 \%$ relative to warming $\left(5^{\circ} \mathrm{C}\right.$ increased). A temperature increase of $5-10^{\circ} \mathrm{C}$ had little effect on the microbial community 


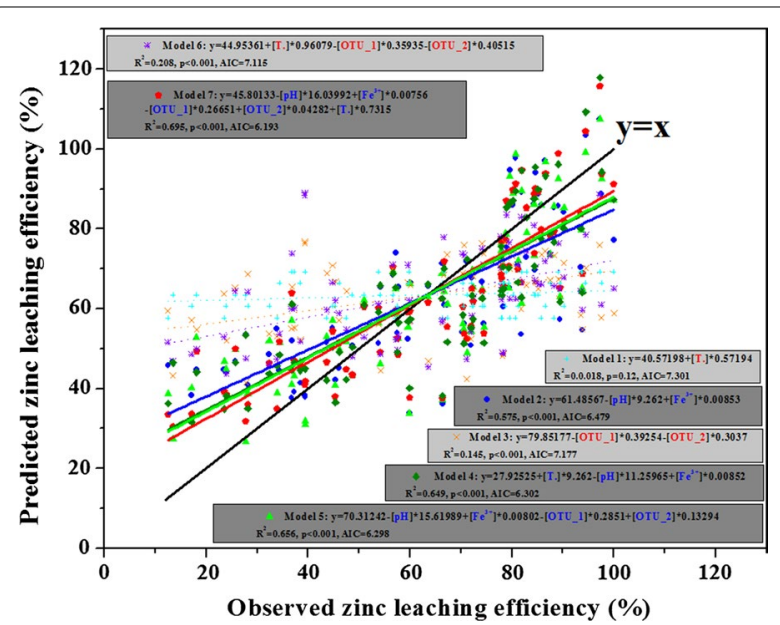

Fig. 6 Models to predict zinc leaching efficiency using multiple linear regression analysis. The variable parameters were temperature, the concentration of ferric iron, $\mathrm{pH}$ value, OTU_1 ( $98 \%$ similarity to $S$. thermotolerans $\mathrm{Kr} 1)$ or OTU_2 (98\% similarity to $\mathrm{A}$. caldus KU)

structure and an increase of $25{ }^{\circ} \mathrm{C}$ shifted the concurrent species, e.g., Arcobacter and Marinobacter (Canion et al. 2014). The temperature sensitivity of microorganisms also applied to bioleaching systems. Although both iron- and sulfur-oxidizing microbes were detected at 33 , 45 and $65{ }^{\circ} \mathrm{C}$, iron-oxidizing microbes (e.g., L. ferriphilum) were the dominant taxa at 33 and $45^{\circ} \mathrm{C}$ and sulfuroxidizing microbes (e.g., uncultured sulfur-oxidizing microbes symbiont bacteria) were the predominant at $65{ }^{\circ} \mathrm{C}$ in column bioleaching of chalcopyrite (Chen et al. 2014). In our study, the taxa occupied the same ecological niche (oxidizing sulfur or iron), e.g., OTU_3 (> 97 similarity to $L$. ferriphilum) and OTU_28 (> 82 similarity to $L$. ferrooxidans), and who would become the winner when they competed with each other was determined by the limiting factors (e.g., temperature) (Bowker et al. 2010; Kreimer et al. 2012). OTU_3 grew better than OTU_28 at the relatively high temperature $\left(35-45{ }^{\circ} \mathrm{C}\right)$, and they showed contrast growth at low temperature $\left(30^{\circ} \mathrm{C}\right)$. This could be well explained by their optimal growth temperature (Gao et al. 2007; Harrison and Norris 1985). Temperature affected the microbial community, via the difference of the generation time of microorganisms, except for growth condition of microorganisms. The generation time of microorganisms could be shortened at a high-growable temperature (Plank and Harvey 1979), indicating that high temperature, to some extent, could accelerate the growth of microorganisms. Furthermore, it was reported that temperature was more important than trophic interaction in influencing microbial community (Gilbert et al. 2012), and the temperature dependence of microbial diversity is greatest at extreme nutrient level (Wang et al. 2016). Our results also showed that microbial community structure was sensitive to temperature, rather than to the OMCs (energy resource).

Temperature affects biological processes (Aragno 1981; Karhu et al. 2014; Williamson et al. 2016; Zhou et al. 2016), via changing microbial community composition, structure and diversity. Furthermore, temperature could alter the activity of enzymes (Bromfield et al. 2011; Razavi et al. 2017). In addition, temperature could alter the chemical dissolution speed of mineral (Chen et al. 2014) and the solubility of bioleaching of product (e.g., jarosite and calcium sulfate) (Sand et al. 2001). Above all, it was indicated that temperature affected sphalerite bioleaching through determining the composition and growth speed of microorganisms. These findings were consistent with our result that zinc recovery increased with increasing temperature in S and SP groups (Fig. 4a).
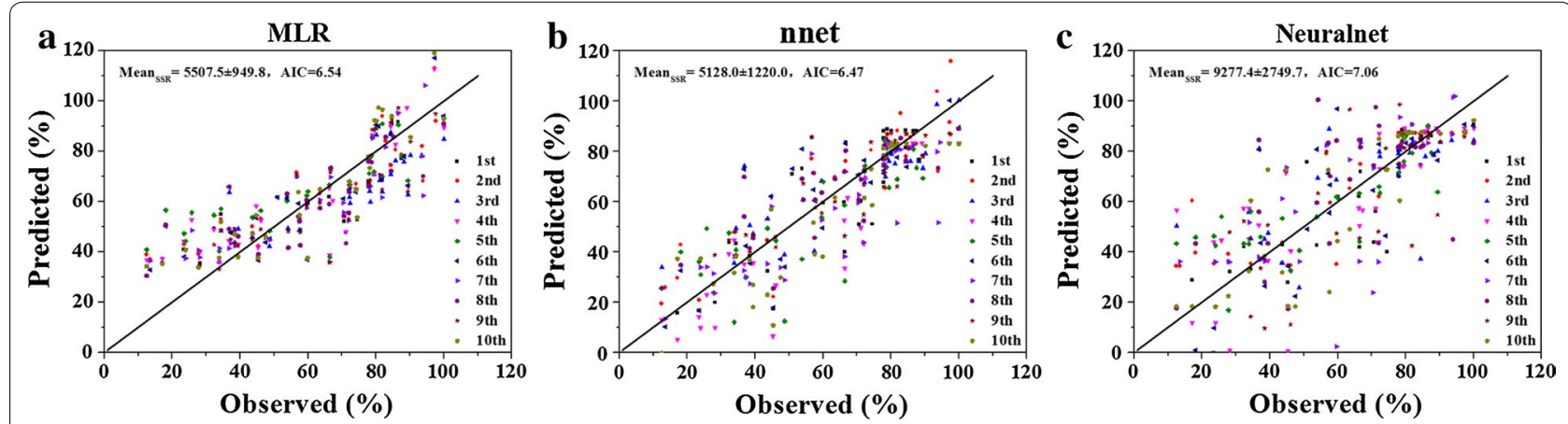

Fig. 7 Comparison of three models to predict zinc leaching efficiency. a MLR model; b nnet model; c neuralnet model. 50 random samples were used to construct the models, and then the remaining 30 samples were predicted (reshuffled 10 times) 


\section{Original mineral composition altered physicochemical parameters and zinc leaching efficiency}

In natural ecosystem, energy resource/fertilization can convert physicochemical parameters (Karami et al. 2012), e.g., $\mathrm{pH}$ and $[\mathrm{Ca}]$. The OMCs as substrates changed energy sources of bioleaching system, following the change of physicochemical parameters (e.g., $\mathrm{pH}$ and $\left[\mathrm{Fe}^{3+}\right]$ ) in leachate as well (Xiao et al. 2015). The dissolution sketch map of 4 different OMCs at $30^{\circ} \mathrm{C}$ was shown in Additional file 1: Figure S4, which showed physicochemical parameters were obviously different among four groups, and PCA and PL-SPM showed that the whole of physicochemical parameters was affected by the OMCs and bioleaching stages, rather than temperature.

Energy resource, leading to changes of physicochemical parameters, is also an important factor to exert influences in microbial community (Bowen et al. 2011; Campbell et al. 2010) in natural ecosystem. In bioleaching system, Ferroplasma is accelerated by copper ions (Zhang et al. 2015), so that it grew well with additions of chalcopyrite (SC and SPC groups). However, due to the energy resource was sufficient, it didn't become a limiting factor and microorganisms were more sensitive to temperature in this condition.

Energy resource/nutrient component plays an important role in the biological process. Zeglin et al. (2016) reported that quantity and source of organic matter affects microbial community structure and function following volcanic eruption. Nitrogen, one of the limiting nutrients for the yield of crops, also has an important function in methane oxidation of rice rhizosphere microbial community (Shrestha et al. 2010). Co-digestion of manure was thought as an efficient approach to enhance the digestion efficiency (Hartmann and Ahring 2005). Our previous study reported that pyrite or chalcopyrite could enhance zinc recovery at $40^{\circ} \mathrm{C}$ (Xiao et al. 2015). Present study indicated that additions of pyrite always enhanced sphalerite dissolution under different temperature $\left(30,35,40,45\right.$ and $\left.50{ }^{\circ} \mathrm{C}\right)$. On the one hand, sphalerite $(\mathrm{ZnS})$ was polysulfide mechanism, while pyrite dissolution mechanism was thiosulfate mechanism (Fig. 7) (Sand et al. 2001). On the other hand, in contrast to sphalerite system (S group), the proportions of iron and sulfur was high in pyrite. Thus, in SP group, additional pyrite: (i) produced higher concentration of ferric iron, which could oxidized minerals as an oxidizer (Crundwell 2003); (ii) decreased pH value, which made more solubilized jarosite (Rodríguez et al. 2003a, b); and (iii) reduced the formation of elemental sulfur (Rodriguez et al. 2003a, b), which would restrict the mineral dissolving. The similar findings were reported by several previous studies (Nazari et al. 2011; Zhao et al. 2015; Lizama and Suzuki 2011) also reported that addition of pyrite enhanced sphalerite bioleaching.

However, other results in our study showed that in SC group, zinc recovery was the highest at 30 and $50{ }^{\circ} \mathrm{C}$ and the lowest at $40{ }^{\circ} \mathrm{C}$, while in SPC group was the highest at $30{ }^{\circ} \mathrm{C}$ and was the lowest at $50{ }^{\circ} \mathrm{C}$, which was not consistent with the regular that metal recovery increased with increasing temperature. The reasons were mainly as follows.

Firstly, the OMCs were complex. When microorganisms could utilize several energy sources in a system, it might be a question which was preferentially oxidized and temperature might affect the choice (Tsai et al. 2003). Tsai et al. (2003) reported that solubilization efficiency of total extractable $\mathrm{Ni}, \mathrm{Zn}, \mathrm{Cu}$ and $\mathrm{Cr}$ was higher (> 90\%) at $37^{\circ} \mathrm{C}$ than that at 25 and $55^{\circ} \mathrm{C}$, while $\mathrm{Pb}$ recovery was the highest $(64.6 \%)$ at $25^{\circ} \mathrm{C}$.

Secondly, the process of sulfide dissolution was also interfered by other physicochemical parameters, other than temperature. The rate of pyrite dissolution was affected by the concentration of sulfate at temperature gradients (Basson et al. 2013). With additional low concentration of sulfate $(3.94 \mathrm{~g} / \mathrm{L})$, the dissolution rate was high at high temperature $\left(65^{\circ} \mathrm{C}\right)$, while with additional moderate concentration of sulfate $(42.1$ and $78.5 \mathrm{~g} / \mathrm{L}$ sulfate), it was high at $50^{\circ} \mathrm{C}$, and with additional high concentration of sulfate $(119 \mathrm{~g} / \mathrm{L})$, it was high at $35^{\circ} \mathrm{C}$.

Thirdly, it might be due to the complexity of Galvanic leaching among three minerals $\left(\mathrm{ZnS}, \mathrm{FeS}_{2}\right.$ and $\left.\mathrm{CuFeS}_{2}\right)$ and the intermediate metabolite (e.g. $\mathrm{CuS}$ ) (Zeng et al. 2011). Galvanic leaching was often ignored (Khmeleva et al. 2005; Lizama and Suzuki 2011), since the effects of microbes and ferric iron/pH were considered to be much more important (Xiao et al. 2015). However, although its effects are weak, it existed actually among these minerals. The electrostatic potential was $\mathrm{ZnS}<\mathrm{CuFeS}_{2}<\mathrm{FeS}_{2}$, and the mineral with higher electrostatic potential could accelerate the dissolution of the mineral with the lower (Mehta and Murr 1982). Galvanic leaching was also affected by temperature and it might be weakened at high temperature.

Besides, it was also might be that the adsorption capacity between different mineral and different microorganisms was different and the adsorption capacity of mineral for microorganisms also shifted under different temperature. Previous study found that compared to the amount of At. ferrooxidans R1 and SP3 attached to chalcopyrite or sphalerite, attachment to pyrite was higher, and compared to chalcopyrite, less amount of strains R1 and more amount of strains SP3 attach to sphalerite (Harneit et al. 2006). Therefore, it might explain why additional chalcopyrite increased zinc leaching efficiency at 
low temperature while decreased it at high temperature. This is also a common phenomenon in natural ecosystem, such that for species turnover rates (one ecosystem function), temperature effects are strongest at intermediate nutrient gradients in subtropical regions, while at two extreme ends of nutrient gradients in subarctic regions (Wang et al. 2016). That is, temperature effect on ecosystem function is versatile in ecosystem with different nutrient/energy resource condition.

\section{Effective models predicting zinc leaching efficiency}

It was always expected to popularize the findings in experiments and provide a certain reference in the future, via constructing feasible predicting models (Venkataraman et al. 2015; Kuang et al. 2016; Pinto et al. 2014). In this experiment, we found that temperature and the OMCs, as well as the variations of microbial community and physicochemical parameters, were all correlated to zinc leaching efficiency. Taking biotic and abiotic factors, we constructed several predicting models, which were meaningful and were the first attempt (to authors' knowledge). In contrast to model 2, model 1 and 3 could not predict sphalerite bioleaching. It suggested that ferric ions and $\mathrm{pH}$ occupied a vital position in sphalerite dissolution (Mousavi et al. 2008). In addition, although OTU_1 and OTU_2 were dominant OTUs, the rare OTUs and their interaction between OTUs might also play important roles in bioleaching process (Lyons and Schwartz 2001; Lyons et al. 2005). Using these five parameters, the predicting model could be optimized and was efficiently connected the biotic and abiotic effects in bioleaching process. It suggested that the cooperation of biotic and abiotic effects was inseparable and significative (Sand et al. 2001). This predicting model might also be applied in other mineral bioleaching system after modified. That was, if the iron/ sulfur concentration, $\mathrm{pH}$ value, temperature and microorganism had been obtained in a natural bioleaching system/mine, the potential metal recovery efficiency might be estimated, which was significative for mine selection in industry applications.

\section{Additional file}

Additional file 1. Supporting materials including supporting experimental methods, figures and tables.

\footnotetext{
Abbreviations

OMCs: original mineral compositions; S: sphalerite; SP: sphalerite adding with pyrite; SC: sphalerite adding with chalcopyrite; SPC: sphalerite adding with pyrite and chalcopyrite; MLR: multiple linear regression; AIC: Akaike information criterion; OTU: operational taxonomic unit; ORP: redox potential; PCA: principal component analysis; DCA: detrended correspondence analysis; PLSPM: partial least squares path modeling.
}

Authors' contributions

Planning and designing of study: $\mathrm{HY}$ and $\mathrm{XL}$; Experimentation: $Y X$ and $X Z$; Data analysis:YX, JF and YL; Manuscript drafting: YX and DM. All authors read and approved the final manuscript.

\section{Author details}

${ }^{1}$ College of Bioscience and Biotechnology and College of Agronomy, Hunan Agricultural University, Changsha 410128, China. ${ }^{2}$ School of Minerals Processing and Bioengineering, Central South University, Changsha 410083, China.

\section{Acknowledgements}

The authors are thankful to the technical staff of the College of Bioscience and Biotechnology and College of Agronomy, Hunan Agricultural University, China, and the staff of School of Minerals Processing and Bioengineering, Central South University, China.

\section{Competing interests}

The authors declare that they have no competing interests.

\section{Ethical approval}

No data was used in this article which needs approval.

\section{Funding}

The study was supported by the National Nature Science Foundation of China (Nos. 31570113 and 41573072), and Graduate Student Research Innovation Project in Central South University (No. 2016zzts105).

\section{Publisher's Note}

Springer Nature remains neutral with regard to jurisdictional claims in published maps and institutional affiliations.

Received: 10 October 2017 Accepted: 14 October 2017

Published online: 23 October 2017

\section{References}

Aragno M (1981) Responses of microorganisms to temperature. Physicological plant ecology, 1st edn. Springer, Berlin

Basson P, Gericke M, Grewar TL, Dew DW, Nicol MJ (2013) The effect of sulphate ions and temperature on the leaching of pyrite. III. Bioleaching. Hydrometallurgy 133:176-181. doi:10.1016/j.hydromet.2013.01.008

Behrad Vakylabad A (2011) A comparison of bioleaching ability of mesophilic and moderately thermophilic culture on copper bioleaching from flotation concentrate and smelter dust. Int J Miner Process 101:94-99. doi:10.1016/j.minpro.2011.09.003

Bonnefoy V, Holmes DS (2012) Genomic insights into microbial iron oxidation and iron uptake strategies in extremely acidic environments. Environ Microbiol 14:1597-1611. doi:10.1111/j.1462-2920.2011.02626.x

Bowen JL, Ward BB, Morrison HG, Hobbie JE, Valiela I, Deegan LA, Sogin ML (2011) Microbial community composition in sediments resists perturbation by nutrient enrichment. ISME J 5:1540-1548. doi:10.1038/ ismej.2011.22

Bowker MA, Maestre FT, Escolar C (2010) Biological crusts as a model system for examining the biodiversity-ecosystem function relationship in soils. Soil Biol Biochem 42:405-417. doi:10.1016/j.soilbio.2009.10.025

Bromfield L, Africa CJ, Harrison STL, Hille RPV (2011) The effect of temperature and culture history on the attachment of Metallosphaera hakonensis to mineral sulfides with application to heap bioleaching. Miner Eng 24:1157-1165. doi:10.1016/j.mineng.2011.03.019

Campbell BJ, Polson SW, Hanson TE, Mack MC, Schuur EA (2010) The effect of nutrient deposition on bacterial communities in Arctic tundra soil. Environ Microbiol 12:1842-1854. doi:10.1111/j.1462-2920.2010.02189.x

Canion A, Overholt WA, Kostka JE, Huettel M, Lavik G, Kuypers MMM (2014) Temperature response of denitrification and anaerobic ammonium oxidation rates and microbial community structure in Arctic fiord sediments. Environ Microbiol 16:3331-3344. doi:10.1111/1462-2920.12593 
Chen B, Wu B, Liu X, Wen J (2014) Comparison of microbial diversity during column bioleaching of chalcopyrite at different temperatures. J Basic Microb 54:491-499. doi:10.1002/jobm.201300092

Conrad R, Klose M, Noll M (2009) Functional and structural response of the methanogenic microbial community in rice field soil to temperature change. Environ Microbiol 11:1844-1853. doi:10.1111/j.1462-2920.2009.01909.x

Crundwell FK (2003) How do bacteria interact with minerals? Hydrometallurgy 71:75-81. doi:10.1016/S0304-386X(03)00175-0

Deangelis KM, Pold G, Topçuoğ lu BD, van Diepen LT, Varney RM, Blanchard IL, Melillo J, Frey SD (2015) Long-term forest soil warming alters microbial communities in temperate forest soils. Front Microbiol 6:104. doi:10.3389/ fmicb.2015.00104

Gao J, Zhang CG, Wu XL, Wang HH, Qiu GZ (2007) Isolation and identification of a strain of Leptospirillum ferriphilum from an extreme acid mine drainage site. Ann Microbiol 57:171-176. doi:10.1007/BF03175203

Garrido P, Gonzalez-Toril E, Garcia-Moyano A, Moreno-Paz M, Amils R, Parro V (2008) An oligonucleotide prokaryotic acidophile microarray: its validation and its use to monitor seasonal variations in extreme acidic environments with total environmental RNA. Environ Microbiol 10:836-850. doi:10.1111/j.1462-2920.2008.01477.x

Gilbert JA, Steele JA, Caporaso JG, Steinbruck L, Reeder J, Temperton B, Huse S, McHardy AC, Knight R, Joint I, Somerfield P, Fuhrman JA, Field D (2012) Defining seasonal marine microbial community dynamics. ISME J 6:298-308. doi:10.1038/ismej.2011.107

Goto K, Tanimoto Y, Tamura T, Mochida K, Arai D, Asahara M, Suzuki M, Tanaka $\mathrm{H}$, Inagaki K (2002) Identification of thermoacidophilic bacteria and a new Alicyclobacillus genomic species isolated from acidic environments in Japan. Extremophiles 6:333-340. doi:10.1007/s00792-001-0262-3

Harneit K, Göksel A, Kock D, Klock JH, Gehrke T, Sand W (2006) Adhesion to metal sulfide surfaces by cells of Acidithiobacillus ferrooxidans, Acidithiobacillus thiooxidans and Leptospirillum ferrooxidans. Hydrometallurgy 83:245-254. doi:10.1016/j.hydromet.2006.03.044

Harrison AP, Norris PR (1985) Leptospirillum ferrooxidans and similar bacteria: some characteristics and genomic diversity. FEMS Microbiol Lett 30:1543-1552. doi:10.1111/j.1574-6968.1985.tb00992.x

Hartmann H, Ahring BK (2005) Anaerobic digestion of the organic fraction of municipal solid waste: influence of co-digestion with manure. Water Res 39(8):1543-1552. doi:10.1016/j.watres.2005.02.001

Justice NB, Norman A, Brown CT, Singh A, Thomas BC, Banfield JF (2014) Comparison of environmental and isolate Sulfobacillus genomes reveals diverse carbon, sulfur, nitrogen, and hydrogen metabolisms. BMC Genom 15:1-17. doi:10.1186/1471-2164-15-1107

Karami A, Homaee M, Afzalinia S, Ruhipour H, Basirat S (2012) Organic resource management: impacts on soil aggregate stability and other soil physicochemical properties. Agric Ecosyst Environ 148:22-28. doi:10.1016/j. agee.2011.10.021

Karhu K, Auffret MD, Dungait JA, Hopkins DW, Prosser JI, Singh BK, Subke JA, Wookey PA, Agren Gl, Sebastià MT (2014) Temperature sensitivity of soil respiration rates enhanced by microbial community response. Nature 513:81-84. doi:10.1038/nature13604

Khmeleva TN, Georgiev TV, Jasieniak M, Skinner WM, Beattie DA (2005) XPS and ToF-SIMS study of a chalcopyrite-pyrite-sphalerite mixture treated with xanthate and sodium bisulphite. Surf Interface Anal 37:699-709. doi:10.1002/sia.2067

Kreimer A, Doron-Faigenboim A, Borenstein E, Freilich S (2012) NetCmpt: a network-based tool for calculating the metabolic competition between bacterial species. Bioinformatics 28:2195-2197. doi:10.1093/ bioinformatics/bts323

Kuang J, Huang L, He Z, Chen L, Hua Z, Jia P, Li S, Liu J, Li J, Zhou J, Shu W (2016) Predicting taxonomic and functional structure of microbial communities in acid mine drainage. ISME J 10:1527-1539. doi:10.1038/ ismej.2015.201

Larsen P, Yang D, Collart FR (2012) Predicting bacterial community assemblages using an artificial neural network approach. Nat Methods 1260:33-43. doi:10.1038/nmeth.1975

Lear G, Bellamy J, Case BS, Lee JE, Buckley HL (2014) Fine-scale spatial patterns in bacterial community composition and function within freshwater ponds. ISME J 8:1715-1726. doi:10.1038/ismej.2014.21
Lizama HM, Suzuki I (2011) Interaction of chalcopyrite and sphalerite with pyrite during leaching by Thiobacillus ferrooxidans and Thiobacillus thiooxidans. Can J Microbiol 37:304-311. doi:10.1139/m91-047

Lyons KG, Schwartz MW (2001) Rare species loss alters ecosystem function-invasion resistance. Ecol Lett 4:358-365. doi:10.1046/j.1461-0248.2001.00235.x

Lyons KG, Brigham CA, Traut BH, Schwartz MW (2005) Rare species and ecosystem functioning. Conserv Biol 19:1019-1024. doi:10.1111/j.1523-1739.2005.00106.x

Mangold S, Valdés J, Holmes DS, Dopson M (2011) Sulfur metabolism in the extreme acidophile Acidithiobacillus caldus. Front Microbiol 2:17. doi:10.3389/fmicb.2011.00017

Mehta AP, Murr LE (1982) Kinetic study of sulfide leaching by galvanic interaction between chalcopyrite, pyrite, and sphalerite in the presence of $T$. ferrooxidans $\left(30^{\circ} \mathrm{C}\right)$ and a thermophilic microorganism $\left(55^{\circ} \mathrm{C}\right)$. Biotechnol Bioeng 24:19-940. doi:10.1002/bit.260240413

Mousavi SM, Yaghmaei S, Vossoughi M, Roostaazad R, Jafari A, Ebrahimi M, Chabok OH, Turunen I (2008) The effects of Fe(II) and Fe(III) concentration and initial pH on microbial leaching of low-grade sphalerite ore in a column reactor. Bioresour Technol 99:2840-2845. doi:10.1016/j. biortech.2007.06.009

Nazari G, Dixon DG, Dreisinger DB (2011) Enhancing the kinetics of chalcopyrite leaching in the Galvanox ${ }^{\mathrm{TM}}$ process. Hydrometallurgy 105:251-258. doi:10.1016/j.hydromet.2010.10.013

Pathak A, Dastidar MG, Sreekrishnan TR (2009) Bioleaching of heavy metals from sewage sludge using indigenous iron-oxidizing microorganisms: effect of substrate concentration and total solids. World Acad Sci Eng Technol 58:525-530

Pinto AJ, Schroeder J, Lunn M, Sloan W, Raskin L (2014) Spatial-temporal survey and occupancy-abundance modeling to predict bacterial community dynamics in the drinking water microbiome. MBIO. doi:10.1128/ mBio.01135-14

Plank LD, Harvey JD (1979) Generation time statistics of Escherichia coli B measured by synchronous culture techniques. J Gen Microbiol 115:69-77. doi:10.1099/00221287-115-1-69

Razavi BS, Liu S, Kuzyakov Y (2017) Hot experience for cold-adapted microorganisms: temperature sensitivity of soil enzymes. Soil Biol Biochem 105:236-243. doi:10.1016/j.Soilbio.2016.11.026

Rodríguez Y, Ballester A, Blázquez ML, González F, Muñoz JA (2003a) New information on the sphalerite bioleaching mechanism at low and high temperature. Hydrometallurgy 71:57-66. doi:10.1016/S0304-386X(03)00174-9

Rodríguez Y, Ballester A, Blázquez ML, González F, Muñoz JA (2003b) New information on the chalcopyrite bioleaching mechanism at low and high temperature. Hydrometallurgy 71:47-56. doi:10.1016/ S0304-386X(03)00173-7

Rosenblatt AE, Schmitz OJ (2016) Climate change, nutrition, and bottomup and top-down Food web processes. Trends Ecol Evol 31:965-975. doi:10.1016/j.tree.2016.09.009

Sanchez G, Trinchera L, Russolillo G (2015) Tools for partial least squares path modeling (PLS-PM). http://www.et.bs.ehu.es/cran/web/packages/plspm/

Sand W, Gehrke T, Jozsa P, Schippers A (2001) (Bio)chemistry of bacterial leaching — direct vs. indirect bioleaching. Hydrometallurgy 59:159-175. doi:10.1016/S0304-386X(00)00180-8

Shannon CE (1948) A mathematical theory of communication. Bell Syst Technol J 27:623-656

Shiers DW, Ralph DE, Watling HR (2014) The effects of nitrate on substrate utilisation by some iron(II)- and sulfur-oxidising Bacteria and Archaea. Hydrometallurgy 150:259-268. doi:10.1016/j.hydromet.2014.07.009

Shrestha M, Shrestha PM, Frenzel P, Conrad R (2010) Effect of nitrogen fertilization on methane oxidation, abundance, community structure, and gene expression of methanotrophs in the rice rhizosphere. ISME J 4:1545-1556. doi:10.1038/ismej.2010.89

Sreekrishnan TR, Tyagi RD, Blais JF (1996) Effect of sulfur concentration on sludge acidification during the SSDML process. Water Res 30:2728-2738. doi:10.1016/S0043-1354(96)00001-2

Streit WR, Schmitz RA (2004) Metagenomics-the key to the uncultured microbes. Curr Opin Microbiol 7:492-498. doi:10.1016/j.mib.2004.08.002

Tsai L, Yu KC, Chen SF, Kung PY (2003) Effect of temperature on removal of heavy metals from contaminated river sediments via bioleaching. Water Res 37:2449-2457. doi:10.1016/S0043-1354(02)00634-6 
Tyagi RD, Sreekrishnan TR, Blais JF, Campbell PGC (1994) Kinetics of heavy metal bioleaching from sewage sludge-III. Temperature effects. Water Res 28:2367-2375. doi:10.1016/0043-1354(94)90052-3

Venkataraman A, Bassis CM, Beck JM, Young VB, Curtis JL, Huffnagle GB, Schmidt TM (2015) Application of a neutral community model to assess structuring of the human lung microbiome. MBIO. doi:10.1128/ mBio.02284-14

Wang J, Pan F, Soininen J, Heino J, Shen J (2016) Nutrient enrichment modifies temperature-biodiversity relationships in large-scale field experiments. Nat Commun 7:13960. doi:10.1038/ncomms13960

Watling HR, Johnson J, Shiers DW, Gibson JAE, Nichols PD, Franzmann PD, Plumb JJ (2016) Effect of temperature and inoculation strategy on Cu recovery and microbial activity in column bioleaching. Hydrometallurgy 164:189-201. doi:10.1016/j.hydromet.2016.05.017

Williamson TJ, Cross WF, Benstead JP, Gíslason GM, Hood JM, Huryn AD, Johnson PW, Welter JR (2016) Warming alters coupled carbon and nutrient cycles in experimental streams. Glob Change Biol 22:2152-2164. doi:10.1111/gcb.13205

Wong JWC, Zhou J, Kurade MB, Murugesan K (2015) Influence of ferrous ions on extracellular polymeric substances content and sludge dewaterability during bioleaching. Bioresour Technol 179:78-83. doi:10.1016/j. biortech.2014.10.099

Xiao Y, Xu YD, Dong W, Liang Y, Fan F, Zhang X, Zhang X, Niu J, Ma L, She S (2015) The complicated substrates enhance the microbial diversity and zinc leaching efficiency in sphalerite bioleaching system. Appl Microbio Biotechnol 99:10311-10322. doi:10.1007/s00253-015-6881-x
Yvon-Durocher G, Allen AP, Bastviken D, Conrad R, Gudasz C, St-Pierre A, Thanh-Duc N, Del Giorgio PA (2014) Methane fluxes show consistent temperature dependence across microbial to ecosystem scales. Nature 507:488-491. doi:10.1038/nature13164

Zeglin LH, Wang B, Waythomas C, Rainey F, Talbot SL (2016) Organic matter quantity and source affects microbial community structure and function following volcanic eruption on Kasatochi Island, Alaska. Environ Microbiol 18:146-158. doi:10.1111/1462-2920.12924

Zeng W, Oiu G, Zhou H, Chen M (2011) Electrochemical behaviour of massive chalcopyrite electrodes bioleached by moderately thermophilic microorganisms at $48{ }^{\circ} \mathrm{C}$. Hydrometallurgy 105:259-263. doi:10.1016/j. hydromet.2010.10.012

Zhang L, Zhou W, Li K, Mao F, Wan L, Chen X, Zhou H, Qiu G (2015) Synergetic effects of Ferroplasma thermophilum in enhancement of copper concentrate bioleaching by Acidithiobacillus caldus and Leptospirillum ferriphilum Biochem Eng J 93:142-150. doi:10.1016/j.bej.2014.10.004

Zhao H, Wang J, Gan X, Zheng X, Lang T, Hu M, Li Y, Qin W, Qiu G (2015) Effects of pyrite and bornite on bioleaching of two different types of chalcopyrite in the presence of Leptospirillum ferriphilum. Bioresour Technol 194:28-35. doi:10.1016/j.biortech.2015.07.003

Zhou J, Deng Y, Shen L, Wen C, Yan Q, Ning D, Qin Y, Xue K, Wu L, He Z, Voordeckers JW, Nostrand JDV, Buzzard V, Michaletz ST, Enquist BJ, Weiser MD, Kaspari M, Waide R, Yang Y, Brown JH (2016) Temperature mediates continental-scale diversity of microbes in forest soils. Nat Commun 7:12083. doi:10.1038/ncomms12083

\section{Submit your manuscript to a SpringerOpen ${ }^{\circ}$ journal and benefit from:}

- Convenient online submission

- Rigorous peer review

- Open access: articles freely available online

- High visibility within the field

Retaining the copyright to your article

Submit your next manuscript at springeropen.com 